\title{
O pão nosso de cada dia: memória imigrante e o pão das gerações curitibanas
}

JULIANA CRISTINA REINHARDT*

\begin{abstract}
Resumo: A Padaria América é a padaria mais antiga de Curitiba em atividade. O comprar e o fazer o pão foi repassado de pai para filho. Neste trabalho, buscamos entender essa tradição, buscando também seus significados, através da história oral. Entendemos que essa tradição foi construída ao longo dos anos e fortalecida nos momentos de tensão e ruptura e que os clientes buscam não um pão qualquer, mas, principalmente, memória e história.
\end{abstract}

Abstract: The Padaria América is the oldest one in Curitiba. The tradition of buying and making bread has passed from father to son. In this article I will try to understand this tradition and, I will look for its meanings trough the oral history. I understand that this tradition, which was built up along the years, was strengthened through moments of tension and rupture and the client's search especially in the memory and history that those rye's breads hide.

Palavras-chave: História da alimentação. Memória. Tradição.

Key words: History of food. Memory. Tradition.

\section{Introdução}

O presente artigo é fruto da dissertação de mestrado realizado pelo programa de pós-graduação em História da Universidade Federal do Paraná, defendido em meados de 2002.

A pesquisa sobre a Padaria América veio a ser realizada pelo fato desta padaria ser a mais antiga de Curitiba em atividade. Fundada em 1913, por Eduardo Engelhardt, a padaria sempre pertenceu e foi administrada por um membro da família do fundador e suas receitas foram repassadas aos seus descendentes. Eduardo Engelhardt transmitiu o ofício de padeiro e suas receitas a seu filho

* Doutoranda pelo Programa de Pós-Graduação em História da Universidade Federal do Paraná. E-mail: julianareinhardt@yahoo.com.br

Estudos Ibero-Americanos. PUCRS, v. XXXII, n. 2, p. 133-153, dezembro 2006 
Ewaldo (mais conhecido como Bruda) e este retransmitiu ao seu neto Eduardo Henrique, hoje o membro da família que detém os conhecimentos da panificação e as receitas da padaria, permanecendo neste ofício. Ainda hoje seus pães, broas, doces, tortas e bolachas são elaborados com métodos artesanais, mantendo receitas do início do século XX. Esta padaria tem em uma considerável parte de seus clientes descendentes de imigrantes europeus, predominando os descendentes de alemães. O comprar o pão nesta padaria também foi repassado de pai para filho. Os clientes de hoje são os filhos e netos dos clientes de ontem.

Neste trabalho buscamos entender a tradição de se fazer e se comprar o pão na Padaria América. O que faz com que a família Engelhardt mantenha a tradição de fazer o pão? O que leva uma determinada clientela a continuar freqüentando esta padaria transmitindo esta tradição a seus filhos e netos? Qual o significado desta padaria e de seus pães para a família Engelhardt e para seus clientes? O que leva esta padaria artesanal a continuar no mercado, sendo que muitos estabelecimentos pequenos e artesanais de sua época desapareceram por não conseguir competir com as indústrias de alimentos, massas semi-prontas, pães e doces feitos em larga escala distribuídos para outros estabelecimentos?

Hoje podemos observar que o mundo artesanal dos padeiros e dos doceiros é atropelado com a chegada da cozinha industrial, pois a padronização é uma condição do fast-food, refeição rápida. ${ }^{1}$ Com esta tendência, vários pequenos estabelecimentos começaram a declinar, padarias e açougues estão sendo gradativamente substituídos pelos grandes estabelecimentos. Muitos não produzem mais seus próprios produtos: os pães e doces agora são produzidos em larga escala e distribuídos às outras padarias e supermercados. Por isso a importância do estudo da permanência de certos estabelecimentos tradicionais.

Na Padaria América o "pão francês", o pão tradicional dos dias de hoje à maioria dos brasileiros, é produzido em pouca quantidade por não ter quase saída. O "carro-chefe", o pão mais vendido nesta padaria, é a broa de centeio, que era chamada "o pão do colono alemão". Os imigrantes trouxeram este hábito alimentar com eles e o comer este tipo de broa foi repassado aos seus descendentes. Este pão ainda é consumido em uma parte da Europa. Porém, para determinada clientela da Padaria América, o comer a broa de centeio produzida pela mesma já não é apenas um

1 ORTIZ, R. Cultura e modernidade-mundo. In: Mundialização e Cultura. São Paulo: Brasiliense, 1994, p. 74-87. 
hábito, mas uma tradição. Veremos, o que fez com que este hábito se instaurasse em uma tradição. Acreditamos que por trás da busca desta clientela por determinado pão existam motivos singulares. Não é apenas a aquisição de um pão qualquer, mas um pão que pode trazer sentimentos, emoções, identidade, história.

A comida pode nos revelar muito mais que nutrientes - lipídeos, proteínas, carboidratos. A comida é o reflexo da organização social, onde os indivíduos elegem o que é "alimento" e o que é "comida", pois, de acordo com Da Matta, alimento é aquilo que pode nos trazer nutrientes, mas nem todo alimento pode se transformar em "comida", por não fazer parte de nossos hábitos. A "comida" é o alimento que vai ser ingerido. Só é "comida" aquilo que é aceito socialmente e culturalmente dentro de um determinado grupo de indivíduos. Estes elegem o que comer, quando, como, onde e com quem, dependendo de inúmeros fatores, como crenças, valores sociais, cultura, costumes, etc. ${ }^{2}$

Dentro da perspectiva de que "o ato de comer cristaliza estados emocionais e identidades sociais" 3 e acreditando que comida, bem como alimento, hoje são entendidos enquanto categorias históricas, ${ }^{4}$ conduzimos este trabalho.

\section{A memória e a história oral}

De acordo com Paul Thompson, a transmissão cultural entre gerações é tão antiga quanto a humanidade. Em contraste com as pretensões da cultura de representar a tradição através dos séculos, está a brevidade da vida humana. Daí a ocorrência universal da transmissão da cultura entre gerações. O papel da família na transmissão cultural entre gerações é também antigo. Inclui não somente a transmissão da memória familiar, mas também da linguagem, da religião, da moradia, do nome, do território, dos valores e aspirações sociais, visões de mundo, habilidades domésticas, etc. ${ }^{5}$

Para entendermos a tradição, que é a transmissão de cultura entre gerações e que ocorre entre a família Engelhardt e seus clien-

2 DA MATTA, R. Sobre o simbolismo da comida no Brasil. In: O correio. Rio de janeiro, v. 15, n. 7, p. 22, julho de 1987.

3 Id.

4 SANTOS, C. R. A

5 THOMPSON, P. A transmissão cultural entre gerações dentro das famílias: uma abordagem centrada em histórias de vida. In: Ciências Sociais Hoje. ANPOCS, 1993, p. 9 
tes, precisamos entender as condições em que ocorrem esta tradição e por que ainda se mantém.

Para responder a nossas questões, foi indispensável produzirmos nossas fontes, através dos depoimentos coletados em entrevistas, utilizando assim a história oral. Somente através dos relatos da família Engelhardt e de seus clientes é que pudemos chegar aos nossos objetivos. Os depoimentos foram obtidos através da reconstrução das memórias de membros da família Engelhardt e de seus clientes. As memórias reconstruídas e coletadas através de entrevistas, testemunhos ou depoimentos, com os devidos cuidados, são transformadas em documentos e podem ser utilizadas como fontes orais. A história oral é um meio privilegiado para o resgate da vida cotidiana, tendo em vista que esta se mantém firmemente na memória.

O uso deste tipo de fonte ainda hoje sofre resistência. Segundo Paul Thompson, esta resistência é a resistência a novos métodos que a geração mais velha de historiadores têm, pois eles devem sempre deter as "rédeas" do conhecimento. A chegada de um novo método implicaria que estes não mais comandariam todas as técnicas de sua profissão. 6 Para Gwyns Prins, há razões mais profundas: os historiadores vivem em sociedades alfabetizadas e inconscientemente tendem a desprezar a palavra falada. ${ }^{7}$

Outro ponto colocado em questão é em relação à subjetividade e à veracidade dos depoimentos. Este ponto é também ultrapassado, na medida em que sabemos que as subjetividades e as dúvidas quanto à veracidade também podem ser encontradas nos documentos escritos. Também é alvo de críticas o fato de a memória individual ser mitológica, não confiável. Para os que defendem este aspecto da memória, a história é propriedade de instituições e historiadores profissionais. Se pensarmos desta forma, substituiremos a memória de milhões de indivíduos pela memória profissional de um grupo de historiadores ou pelas memórias institucionais. ${ }^{8}$

Para Philippe Joutard, os que contestam a fonte oral travam combates ultrapassados, e explica o porquê:

6 THOMPSON, P. A voz do passado - história oral. Rio de Janeiro: Paz e Terra, 1992.

7 PRINS, G. História Oral. In: A escrita da história. São Paulo: Editora da UNESP, 1992, p.163.

8 PORTELLI, A. Memória e diálogo: desafios da história oral para a ideologia do século XXI. In: História oral: desafios para o século XXI. Rio de Janeiro: Editora Fiocruz/Casa de Oswaldo Cruz/CPDOC - Fundação Getúlio Vargas, 2000, p. 69. 
O oral nos revela o "indescritível", toda uma série de realidades que raramente aparecem nos documentos escritos, seja porque são consideradas "muito insignificantes" (é o mundo da cotidianidade) ou inconfessáveis, ou porque são impossíveis de transmitir pela escrita (...). É através do oral que se penetra no mundo do imaginário e do simbólico, que é tanto motor e criador da história quanto o universo racional. (...) a história oral é uma via de acesso privilegiada a uma história antropológica e deve continuar a sê-lo. ${ }^{9}$

São estas questões subjetivas, que fazem com que possamos chegar ao mundo imaginário e simbólico dos indivíduos que recorremos a esta metodologia, podendo entender o significado da padaria e de seu pão a seus clientes e sua família. "A opção pela memória se dá porque o que nos interessa são situações vividas, lembranças que, embora possam parecer insignificantes à primeira vista, após a análise, poderão se mostrar plena de significados”. ${ }^{10}$ Além disso, a metodologia em questão permite ultrapassar as individualidades, atingindo características grupais. ${ }^{11}$ Segundo Myriam M. Lins de Barros, a compreensão comum dos símbolos e dos significados e a comunhão de noções que compartilhamos com os membros do grupo social definem o caráter social das memórias individuais. ${ }^{12}$

As pessoas escolhidas para os depoimentos foram selecionadas por pensar que estas prestariam as informações sobre o assunto pesquisado. Assim sendo, foram desenvolvidas entrevistas primeiramente com membros específicos da família Engelhardt: Alfonso Eduardo Engelhardt (Alfonso), neto do fundador e dono da padaria juntamente com os filhos; ${ }^{13}$ Eduardo Henrique Engelhardt (Eduardo Henrique), bisneto do fundador e atual membro da família que permanece como padeiro; Waldemar Arthur Engelhardt (Dr. Waldemar), sobrinho do fundador, e Lindamir Gumz Lechenakoski (Lindamir), caixa da padaria desde 1960. Estas pessoas estão dentro do grupo ao qual denominamos "Família América".

Posteriormente foram realizadas entrevistas com clientes "tradicionais" da padaria. Através dos relatos dos primeiros depo-

9 JOUTARD, P. Desafios à história oral para o século XXI. In: História oral: desafios para o século XXI. Rio de Janeiro: Editora Fiocruz/Casa de Oswaldo Cruz/CPDOC Fundação Getúlio Vargas, 2000, p. 34.

10 BERNARDO, T. Memória em branco e negro: olhares sobre São Paulo. São Paulo: EDUC: Fundação Editora da UNESP, 1998, p. 29.

11 Esta é a característica da chamada memória coletiva ou social, teorizada por Maurice HALBWACHS. Ver: HALBWACHS, M. A memória coletiva. São Paulo: Vértice, 1990.

12 BARROS, M. M. Lins de. Memória e família. Estudos Históricos, vol. 2, n. 3, Rio de Janeiro, 1989, p. 30.

13 Alfonso tem $80 \%$ da padaria, e seus filhos Eduardo Henrique e Andréa $10 \%$ cada um. 
entes, os chamados de "Família América", soubemos da ocorrência de clientelas distintas.

Eduardo Henrique, afirma que existem duas clientelas completamente diferentes: a do dia de semana e a dos sábados: "nós temos clientes que vêm todo dia e temos clientes que só vêm aos sábados. Por exemplo, a nossa clientela de sábado é diferente da freguesia do dia de semana. É completamente diferente". ${ }^{14}$ Eduardo conta que este cliente geralmente mora mais longe, por isso aos sábados ele pode despender um maior tempo se deslocando até a padaria:

É um cliente que às vezes compra mais de uma broa, para deixar durante a semana, para congelar e para ter durante a semana. É um cliente que admira mais doces, cuques e outras especiarias também. São os descendentes (...). Existe até uma tradição. Porque são fregueses que se encontram, amigos que se encontram na fila da padaria, aquela coisa assim. E começam a bater papo na fila da padaria. Então virou um programa de sábado: vamos na América comprar o pão.

Em relação a estes clientes, Lindamir comenta: "Aqueles lá você pode olhar que são tudo freguês antigo. Quando não vem a mãe vem o filho, quando não vem o filho vem o neto". ${ }^{15}$ Lindamir também afirma que vários deles compram pão para toda a semana: "Eles põem no freezer e tem alguns que guardam num sacão. Sabe, esses alemães antigos, eles gostam do pão amanhecido. Que nem minha tia: minha tia fazia, por exemplo, o pão no sábado e ia até no outro sábado. E aqui são os nossos fregueses. Se dia de semana, vamos contar que vendam 1.000 broas. No sábado vendem 2.000". O que estes fregueses compram também diferencia. Os clientes que vêm durante a semana, que são os brasileiros, "os tradicionais de hoje" segundo Lindamir, compram o pão francês, e o querem "fresquinho, torradinho, quentinho na hora. Não só o pão francês, mas também a broa, eles querem quentinha".

Eduardo Henrique, então, define sua clientela: "É o filho e o neto do freguês do meu avô e do meu bisavô. É esse o nosso freguês. Porque ele nasceu comendo nosso pão e ele vai continuar comendo o nosso pão e o filho dele vai comer o nosso pão".

\section{A comida despertando lembranças}

14 ENGELHARDT, Eduardo Henrique. ENTREVISTA. Curitiba, 7 de agosto de 2000.

${ }^{15}$ LECHENAKOSKI, Lindamir Gumz. ENTREVISTA. Curitiba, 4 de agosto de 2000. 
Acreditamos que as lembranças mais puras e genuínas são aquelas despertadas através dos sentidos, pois são sentidas através das sensações, não da consciência. Diversos autores, entre eles, Marcel Proust, Isabel Allende, Luce Giard, Rachel de Queirós e Nina Horta escreveram sobre este tema fazendo com que fôssemos transportados aos seus mundos literários vivenciando também suas lembranças. É assim quando falamos em sentidos: cheiros, sons, imagens, texturas, gostos.

Marcel Proust, em sua obra "O tempo redescoberto", 16 nos remete a maior parte do tempo a um retorno ao passado, quando vêm à tona suas lembranças despertadas pelos sentidos. Um exemplo clássico são as lembranças despertadas por suas madeleines molhadas no chá. É este autor que afirma que as memórias sensitivas, como as gustativas e olfativas são as mais puras e genuínas que temos, pois são sentidas através das sensações, não da consciência. "O odor e o sabor suportam durante muito tempo ainda, sem ceder, sobre sua reduzida esfera, o imenso edifício da lembrança". ${ }^{17}$ Nas obras de Marcel Proust a comida é transfigurada em obra de arte. 18

Quando comemos alguma coisa que fazia parte de nosso cardápio de tempos atrás, quando sentimos um gosto característico e dizemos "isto tem gosto de infância", sentimos que se inicia uma viagem no tempo em que podemos sentir cheiros, imagens, sons característicos. Parece que retrocedemos e voltamos a lugares há muito não vistos, nos vemos novamente nas diversas paisagens da infância, lembramos de gestos, de palavras, e o melhor: de sensações. São estas lembranças que Proust revela.

Luce Giard compartilha desta teoria. Conta que sempre havia fugido da cozinha de sua mãe, por não concordar com aquela função delegada ao sexo feminino: "Eu detestava aquele serviço de mulher, porque jamais era pedido ao meu irmão". ${ }^{19}$ Mesmo constatando que jamais havia aprendido coisa alguma sobre cozinhar, pois sempre preferiu seu quarto, seus livros, seus jogos à cozinha constatou:

meu olhar de criança viu e memorizou gestos, meus sentidos guardaram a lembrança dos sabores, dos odores e das cores. Já me eram

16 PROUST, M. Em busca do tempo perdido: o tempo redescoberto. 12. ed. São Paulo: Globo, 1995.

17 PROUST, M. Em busca do tempo perdido: o caminho de Swann. 15. ed. São Paulo: Globo, 1993, p. 68.

18 COSNIER, C. Gastronomia de Proust. In: Marcel Proust: o homem/o escritor/a obra. Rio de Janeiro: Editora Civilização Brasileira, 1971, p. 204-218.

19 GIARD, L. Cozinhar. In: A invenç̧ão do cotidiano. Petrópolis: Vozes, 1996, p. 213. 
familiares todos esses ruídos: o borbulhar da água fervendo, o chiar da gordura derretendo, o surdo ruído de fazer a massa com as mãos. Bastariam uma receita ou uma palavra indicativa para suscitar uma estranha anamnese capaz de reativar, por fragmentos, antigos sabores e primitivas experiências que, sem querer, havia herdado e estavam armazenadas em mim. ${ }^{20}$

Em seu livro O Não Me Deixes - suas histórias e suas cozinhas, Rachel de Queirós organiza lembranças e receitas da cozinha sertaneja. É no sertão nordestino que está "Não Me Deixes", fazenda da autora, onde seus filhos e netos passaram parte de sua infância. Flávio Queirós, neto de Rachel, revela nesta obra:

Minhas lembranças (...) também contêm as memórias de sabores até hoje sobreviventes. Ir para o Não Me Deixes significava mudar completamente os gostos e cheiros, pois a cozinha sertaneja é muito diferente da que comemos aqui no sul. Até hoje, quando me sento à mesa da Fazenda, ao provar o feijão-de-corda temperado com coentro fresco e nata de leite, sinto a lembrança daquele mesmo sabor e do seu impacto distante. $\mathrm{O}$ arroz com colorau e o leite grosso são outros dois sabores que me lembro. (...). Um cheiro que também não posso me esquecer era o do café, principalmente quando estava sendo torrado...21

Para Nina Horta, outro tipo de comida que lembra a infância é a denominada "comida de alma". É a comida que consola, que deve ser comida nos momentos de tristeza, na hora da dor, da depressão. Ela deve escorregar garganta abaixo sem precisar ser mastigada. Ela conforta a alma, dá segurança, "lembra a infância e o costume". 22

Entendendo também a comida enquanto "despertador" da memória, acreditamos que um dos motivos que faz com que os clientes continuem a freqüentar a Padaria América é a procura nos pães, doces, tortas e bolachas da padaria um meio para despertar suas lembranças.

Sempre quando eu entro na padaria eu me lembro assim, de antigamente, quando eu estudava no colégio, às vezes depois da aula, nós íamos ali, eu e minhas amigas, então aquilo me recorda assim, sabe, aquela coisa antiga assim de dizer "nossa há quantos anos eu vinha aqui”. (...). Às vezes a gente vê algumas caras conhecidas as-

20 Ibid., p. 214.

21 QUEIRÓS, R. de. O Não Me Deixes - suas histórias e sua cozinha. São Paulo: Siciliano, 2000, p. 16-17.

22 HORTA, Não é sopa - crônicas e receitas de comida. São Paulo: Companhia das Letras, 1995, p. 15. 
sim. (...). Então me lembra isso, infância. Infância, Padaria América. Então a gente sempre tem essa recordação. ${ }^{23}$

Jaqueline, cliente da padaria, também vincula suas lembranças ao espaço, que é uma das formas de trazer nossas lembranças à tona. Michael Pollak relata a força que estes diferentes pontos de referência que estruturam nossa memória exercem sob a memória coletiva: os monumentos, os patrimônios arquitetônicos, as paisagens, as datas, os personagens históricos, a música, o folclore, as tradições e os costumes e as tradições culinárias. ${ }^{24}$

As noções de tempo e de espaço, que são a estrutura dos quadros sociais da memória, são fundamentais para a lembrança do passado, na medida em que as localizações no espaço e no tempo das lembranças são a essência da memória, de modo que, quando o quadro espacial se transforma ou desaparece, a lembrança é ameaçada. Neste ponto, não podemos deixar de lembrar que a padaria objeto de nossa pesquisa encontra-se no mesmo lugar há 78 anos e nos 15 anos anteriores estava a uma quadra de sua atual localização.

Segundo Antônio César de Almeida Santos construímos nossos espaços ao longo de nossa vida porque lhes atribuímos significados. Os espaços que vão sendo construídos em nossas vidas são produzidos de acordo com nossas relações com os outros, mais íntimos ou não. 25

Como concordamos que as lembranças vindas através dos sentidos são as mais genuínas que existem, entendemos a forma que faz com que Jaqueline se lembre. É através de imagens que é despertada a sua memória. A padaria está no mesmo lugar durante todo este tempo em que ela a freqüentou e, segundo os depoimentos dos clientes, mudou muito pouco internamente, somente em alguns detalhes, como conta outra cliente da padaria, D. Carmem: "Porque há muitos e muitos e muitos anos ela está daquele jeitinho, naquele lugar. (...) o jeito da padaria faz lembrar o meu tempo de criança!".26

Mesmo inconscientemente, estes pães e doces trazem para nossos depoentes um estado de nostalgia, despertando lembranças, recordações. Fazendo com que ocorra uma breve viagem no

23 BOUTIN, Jaqueline. ENTREVISTA. Curitiba, dia 30 de junho de 2001.

24 POLLAK, M. Memória, esquecimento, silêncio. Estudos Históricos, vol. 2, n. 3, Rio de Janeiro, p. 3.

25 SANTOS, A. C. de A. Memórias e cidade - depoimentos e transformação urbana de Curitiba (1930 - 1990). 2. ed. Curitiba: Aos Quatro Ventos, p. 21.

26 GARMATTER, Carmem Klas. ENTREVISTA. Curitiba, 3 de julho de 2001. 
tempo, retornando à infância, à adolescência, confirmando as teorias de Marcel Proust, Isabel Allende, Rachel de Queirós, Luce Giard, Nina Horta.

Se lembramos, é porque os outros, a situação presente, nos faz lembrar. A memória da pessoa é amarrada à memória do grupo, e esta última à esfera da tradição, que é a memória coletiva de cada sociedade. ${ }^{27} \mathrm{O}$ ato de comer se torna um verdadeiro discurso do passado e o relato nostálgico do país, da região, da cidade ou do lugar em que nasceu.

Na fala de D. Carmem está explícito um dos motivos que a faz continuar a freqüentar a padaria: "eu vou lá porque eu gosto. Me acostumaram assim também. Para mim é a melhor broa de Curitiba, porque eu aprendi assim também. Talvez até tenha outra em volta por aí que eu não experimentei". ${ }^{28}$ Além de D. Carmem gostar, afirmando a importância do "gosto", está outro motivo "me acostumaram a ir lá". Ela não sabe explicar bem o porquê. O motivo é que a "acostumaram" a ir. E, a partir do momento em que ela própria começa a freqüentar a padaria comprando as mesmas coisas que seus pais compravam, ela renova a tradição.

O "acostumar" a que D. Carmem se refere, vem no sentido de "ensinar". De acordo com Luce Giard, nós comemos o que nossa mãe nos ensinou a comer ou, no caso dos homens, o que a mãe de sua esposa lhe ensinou a comer. "É mais lógico acreditar que comemos nossas lembranças, as mais seguras temperadas de ternura e de ritos, que marcaram nossa primeira infância". ${ }^{29}$ Acreditamos, também, que o contrário pode ocorrer, ou seja: comemos também o que nossos pais nos ensinaram a comer e o que a mãe de nosso marido lhes ensinou a comer. ${ }^{30}$

Petra, outra cliente, também menciona que foi "acostumada" e diz que é a tradição:

quando a gente voltou da Europa, primeira coisa que a minha mãe disse. De tarde, eu estava cansada, fuso horário arrebentado, tudo. A mãe olhou para mim e disse: "quem que vai na Padaria América comprar minha broa?" Então você fica, porque é uma coisa que você está acostumada a comer e você gosta, você vai buscar de novo. En-

27 HALBWACHS, op. cit.

28 Id.

29 GIARD, op. cit., p. 249-250.

30 Na casa da autora deste trabalho, várias tradições alimentares ocorrem por transmissão do pai da mesma. O próprio comprar e comer a broa da Padaria América foi transmitido pelo pai. E, hoje, não só nós, os filhos compramos esta broa, como também nossa mãe. 
tão é tudo. É a saudade, é a vontade... É a tradição. Acho que é isso... ${ }^{31}$

Aline confirma a manutenção da tradição: "comprava quando eu era menina as mesmas coisas praticamente". Quando questionada sobre qual a diferença do pão da Padaria América para o pão de outras padarias, Aline responde: "Tem o segredinho, não é? Parece que é diferente das outras padarias. Ou talvez por eu já estar acostumada com o gosto, desde pequena... Não sei. Mas é diferente, é diferente".

A importância da tradição está também implícita no depoimento de Hyzir, quando ele relata comprar os pães que o pai comprava - a broa de centeio, o chifrinho e o pão sovado - nos dias em que seu pai comprava: "Trocar por outro? No final de semana? Não. Não deixaria, não. (...). Porque eu acho que é o melhor pão que tem. Pelo menos na cidade, para o final de semana é o deles".32

Para Hyzir, este é o pão do final de semana. "... meu pai sempre acostumou a gente a comer broa". Ele foi "acostumado" por seu pai a comer a broa. E seu pai também a comprava nos finais de semana. Então este é o pão destinado a comer nestes dias. Aqui observamos o quanto a comida está cercada de rituais: o que comer, bem como a forma, quando, onde e com quem são estipulados pelos indivíduos situando-os dentro de uma determinada cultura e sociedade. Para a família de Hyzir, este é o pão do final de semana, o que não ocorre com outros clientes. Alguns o elegem como o pão de todo dia, ou o pão para ocasiões especiais, ou o pão para comer quando tem vontade de algo diferente ou o pão para matar as saudades. Este pão, apesar de ser o mesmo, é eleito para diferentes ocasiões por estes diferentes indivíduos.

Há diferenças entre o comer cotidiano e o comer cerimonial. Antônio Greco Rodrigues afirma que as pessoas tendem a ritualizar tudo que é importante e isto se dá também com as ações voltadas para a alimentação. Normalmente o que exige mais elaboração é transferido para o campo da comida cerimonial. As comidas típicas são próprias da mesa cerimonial e é considerada típica aquela comida que é a especialidade de cada região. Antônio Grecco nos dá de exemplo a comida típica de sua região: Minas Gerais. Em Minas, comida típica é a comida de fazenda, ou seja: feijão tropeiro, lombo de panela, pernil assado, vaca atolada, frango ao molho pardo, tutu à mineira, couve picadinha, lingüiça, além dos queijos,

31 MAKAROV, Petra. ENTREVISTA. Curitiba, 19 de junho de 2001.

32 BACOVIS, Hyzir Júnior. ENTREVISTA. Curitiba, 3 de outubro de 2000. 
doces de frutas e de ovos. Essa comida não faz parte do cotidiano das pessoas dos centros urbanos por serem muito trabalhosas, pois são feitas em fogões à lenha ou em fornos de barro, e possuem alto custo. Por isso, este tipo de comida típica faz parte da mesa cerimonial.

Restaurantes tentam recriar este tipo de comida regional para atender ao turismo, e às pessoas que desejam conhecer os sabores de outros lugares. Mas, de acordo com o autor, não é só o turista que procura os restaurantes típicos. A população local também procura por ela com muita freqüência:

Ali elas buscam satisfazer uma necessidade criada pela nostalgia que vem da lembrança da vida nas pequenas cidades, ou mesmo nas fazendas, de sua origem familiar. As pessoas buscam, nestes restaurantes, recriar a memória da infância distante, consumindo os pratos típicos que lhe são oferecidos e que são os mesmos que faziam parte do almoço de domingo da casa da vovó, conservados tanto na memória afetiva quanto na gustativa. ${ }^{33}$

Isto é o que ocorre também com muitos dos clientes tradicionais da Padaria América. Lá é feito o pão típico dos europeus que eles eram "acostumados" - no sentido de "ensinados" - a comer na infância, em sua casa, na casa da tia, ou na casa da avó. Alguns eram "acostumados" a comer a "broa do Engelhardt" 34 diariamente, outros em ocasiões especiais. Hoje, eles tentam recuperar esta memória afetiva, mantendo a tradição transmitida por seus familiares, ritualizando o seu comer.

Eduardo Henrique acha que seus produtos trazem prazer aos fregueses: "Ele deve trazer prazer, não é? Eu acho... Porque a comida traz prazer. O sabor traz prazer. Eu queria que ele trouxesse muito prazer para meu freguês, com certeza". Esta indagação de Eduardo é confirmada por alguns clientes quando perguntados o que os leva a comprar o pão da Padaria América: "Então eu não sei, eu gosto do sabor. (...) você sente prazer em comer aquele pãozinho. Não é qualquer pão que você come e, às vezes, nem tem gosto. É um prazer"; 35 "Um pão gostoso"; 36 "Por causa da broa, que achamos que é a melhor que tem por aí". ${ }^{37}$

33 RODRIGUES, A. G. Comida típica - comida ritual. Texto apresentado na $23^{\text {a }}$ Reunião Brasileira de Antropologia, em Gramado-RS, 16-19 de junho de 2002.

34 Alguns clientes nomearam a broa com o sobrenome dos donos da padaria.

35 BOUTIN, Ivo. ENTREVISTA. Curitiba, 15 de junho de 2001.

36 BOUTIN, ibid.

37 KREDER, Walter. ENTREVISTA, Curitiba, 10 de maio de 2001. 
Este prazer ao qual Eduardo Henrique se refere, também tem relação com o conceito de "gosto" usado por Flandrin e Santos para definir sabor. A pessoa só vai sentir prazer em comer seu produto se o achar "gostoso", ou seja, com sabor bom.

Segundo Flandrin, a antiga dietética solicitava que se seguisse à risca o que o seu "gosto" sugeria, pois quanto mais saboroso o "gosto" para seu paladar, mais saudável e nutritivo era este alimento. Acreditava-se que o que era mais agradável ao "gosto" era, por conseguinte, de mais fácil digestão. Também para Carlos Roberto Antunes dos Santos este conceito denominado de "gosto", é uma sensação e resulta do efeito da combinação de informações que procedem de diversos outros sentidos. Estes sentidos têm por origem os receptores dos lábios (frio e quente), da língua (doce e salgado, amargo e azedo) e o olfato, que recebe a informação do cheiro do alimento. O "gosto" é uma combinação do paladar com o olfato. Seria por isso que quando estamos gripados, quando nosso olfato não "funciona", não sentimos o gosto da comida. ${ }^{38}$

Porém, para Bourdieu, o "gosto" não é apenas uma combinação de sentidos. O "gosto" - não apenas o alimentar - e o estilo de vida de cada indivíduo são vinculados ao habitus de uma dada sociedade. Sendo o habitus um "sistema de disposições duráveis e transferíveis, sob a forma de preferências sistemáticas, as necessidades objetivas das quais ele é o produto". ${ }^{39}$ Neste sentido, segundo Bonin e Rolim, os hábitos alimentares são a prática deste habitus: "o gosto por determinado alimento é engendrado a partir do estilo de vida das pessoas, que por sua vez, se vincula à sua classe social e ao habitus de uma sociedade". 40

Tomemos agora, o conceito de "gosto" de Bourdieu e analisemos como este "gosto" se modifica entre os clientes da padaria. Alguns clientes - segundo Lindamir, os brasileiros - gostam de comer o pão no mesmo dia em que foi comprado, gostam do pão fresco. Outros, os alemães antigos, também segundo Lindamir, compram pão para toda semana e o guardam no freezer, e era Bruda quem já indicava que esta era a forma de guardar o seu pão: "embrulhar em um pano ou em um pacote e colocá-lo na geladei-

38 Ver FLANDRIN, J. L. Tempero, cozinha e dietética nos séculos XIV, XV e XVI. In: FLANDRIN, J. L. \& MONTANARI, M. (orgs.). História da Alimentação. São Paulo: Estação Liberdade, 1998, p. 485; e SANTOS, C. R. A. dos. Por uma História da Alimentação. História: questões e debates, n. 26/27, Curitiba: APAH, 1997, p. 162.

39 BOURDIEU, P. Gostos de classe e estilos de vida. In: Ortiz, Renato (org). Sociologia coletânea. São Paulo: Ática, 1983, p. 82-83.

40 BONIN, Anamaria Aimoré; ROLIM, Maria do Carmo. Hábitos alimentares: tradição e inovação. Boletim de Antropologia, Curitiba, v. 4, n. 1, p. 75-80, junho de 1991. 
ra”. Seu Ivo é um destes clientes que tem o hábito de guardar o pão na geladeira ou no freezer: "uma vez por semana a gente compra e tem para vários dias".

Dona Elfi ${ }^{41}$ gosta de comer sua broa com bastante manteiga e mel. "... hoje eu não posso mais porque sou diabética". Sua sobrinha prefere só com mel e seu marido gosta da broa com banha, torresmo e alho por cima, "mas hoje ele não pode mais também, por causa do colesterol". Aqui observamos que estes gostos têm de ser negligenciados também em benefício da saúde - um dos fatores para a mudança ou adaptação de hábitos alimentares.

O sabor do pão é o mesmo, mas o gosto destas pessoas se modifica. O gosto é pessoal. Cada indivíduo influenciado pela sua cultura, pela família, pelos amigos, pelo estilo de vida e por outras relações elege o que é "gostoso" e a ocasião para se comer.

De acordo com Luce Giard, um tipo de comida que necessita de ocasiões específicas é a comida cerimonial, denominada "tradicional". Ela, com seus ritos de composição, de preparação e de consumo - reservada ao dia de sábado; às festas religiosas; à história familiar como casamentos, nascimentos, aniversários, se torna a manutenção e a "narração da diferença, inscrita na ruptura entre o tempo alimentar do 'si-mesmo' e o tempo alimentar do outro". ${ }^{42}$

Como diz Petra: "Então é tudo. É a saudade, é a vontade... É a tradição. Acho que é isso...43

\section{A tradição}

Foi através dos primeiros depoimentos em que percebemos que este conceito estava, de uma maneira ou de outra, vinculado à padaria, que chegamos à nossa problemática: "entender a tradição de se fazer e se comprar o pão na Padaria América". No decorrer das entrevistas feitas com os clientes, a palavra tradição também inúmeras vezes foi mencionada.

Primeiramente devemos entender que esta foi uma tradição construída ao longo dos anos. No início do século XX, quando a padaria foi fundada, havia o "costume" de se comprar o pão na Padaria América por pessoas que moravam perto ou passavam próximo à padaria, como fazemos hoje com tantas padarias presentes em nossa cidade. A partir do momento em que as famílias mudam de bairro e, mesmo morando longe, continuam a freqüen-

41 HARLEZKI, Elfi Ruth. ENTREVISTA. Curitiba, 23 de maio de 2000.

42 GIARD, op. cit., p. 250.

43 MAKAROV, loc. cit. 
tar a padaria que freqüentavam antes, em determinados dias, inicia-se o processo da tradição. E esta será sempre renovada na medida em que os filhos destes clientes passarem a comprar o pão nesta padaria.

Se antes a broa de centeio era o pão de todo dia, hoje este pão não é mais um pão qualquer, mas o pão da Padaria América. O que era um pão comprado por praticidade, transformou-se em um pão que as pessoas cercaram de significados, de cerimônias. A broa de centeio passa a ser denominada por seus clientes como a "a broa da dona Elza" ou a "broa do Engelhardt". E, também a padaria é vinculada ao nome da família, como conta D. Carmem: "Até hoje eu digo: 'eu vou lá no Engelhardt!'. Eu não digo 'Padaria América'. Às vezes alguém fala comigo: 'lá na Padaria América...'. Padaria América? Eu fico pensando... Porque nós aqui, entre a gente, a gente costuma dizer "vou no Engelhardt". Alfonso conclui: "É a tradição, não é?" Ele sabe que é o nome da família que está sendo aprovado ou não. Por isso, Alfonso diz que mesmo não gostando do comércio, trabalharia na padaria "pra manter a tradição, o sobrenome...".

Aqui em nosso trabalho não nos cabe verificar o momento exato em que este costume se transforma em tradição. Sabemos, no entanto, que a tradição se implantou e se fortaleceu nos momentos de transformação, momentos de ruptura como as inovações, que representam a ruptura do presente com o passado.

De acordo com Gerd A. Bornheim, os conceitos opostos costumam atrair-se, formando, de algum modo, uma unidade, ainda que conflituada. Eles "avançam em sua oposição, e chegam a construir uma nova e harmoniosa unidade". ${ }^{44}$ Ainda segundo este autor,

A tradição só parece ser impertubavelmente ela mesma na medida em que afasta qualquer possibilidade de ruptura, ela se quer perene e eterna, sem aperceber-se de que a ausência de movimento termina condenando-a à estagnação da morte. A necessidade da ruptura se torna, em conseqüência, imperiosa, para restituir a dinamicidade ao que parecia 'sem vida'. 45

Os momentos de ruptura que ocorreram durante este processo de "tradição da Padaria América" estão intimamente ligados às mudanças ocorridas na cidade. Mudanças sociais, econômicas e políticas.

44 BORNHEIM, G. A. O conceito de tradição. In: BOSI, A. (org) Cultura brasileira: tradição/contradição. Rio de Janeiro: Zahar, 1987, p. 15. 
Eduardo nos relatou que alguns clientes, quando souberam da morte de Bruda, falaram que o pão não iria mais ser o mesmo. Eles não sabiam que já fazia cerca de dois anos que Bruda não mais fazia o pão, por já estar doente. Ele permaneceu fazendo apenas produtos menos trabalhosos. Outros, segundo Lindamir e Eduardo Henrique, ficaram sabendo da troca dos fornos a gás, pelo forno à lenha, apenas mais tarde, e só então passavam a mencionar uma diferença no sabor. Eduardo conta que alguns falavam: "ah, mudou? É. Realmente não é a mesma coisa...”. E há os que não perceberam a mudança, e dizem que a broa está mais gostosa. Lindamir conta que os clientes dizem: "O que aconteceu que a broa está mais gostosa? Mudou os padeiros?' E eu digo: 'Não, não'. Mas a gente também não comenta que é o forno. (...). Senão eles acham ruim".

Assim observamos o receio de todos, em maior grau dos clientes, que o "sabor" se modifique; a preocupação em manter a qualidade, em maior grau por parte da família, e o esforço realizado de ambas as partes - família Engelhardt e clientes - para acreditar que tudo está igual, para que a tradição permaneça.

$\mathrm{Na}$ padaria, temos alguns exemplos do que Eric Hobsbawm qualifica como "tradição inventada". ${ }^{46} \mathrm{Um}$ dos exemplos é em relação ao uniforme dos padeiros. Segundo Alfonso e Eduardo, somente depois que eles assumiram a administração da padaria é que foi adotado um uniforme para os padeiros. Roupa branca e avental para todos, bonés para os padeiros. Hoje, Eduardo Henrique voltou a usar o chapéu que usava quando o avô era vivo, antes da adoção do uniforme. Ele relata que usava o boné por ser mais prático e segundo a irmã de Eduardo, foi ela quem insistiu para que ele voltasse a adotar o antigo chapéu, usado por ele e pelo avô e feito por sua mãe.

A manutenção deste chapéu não tem um sentido prático. $\mathrm{O}$ que é usado hoje na parte da "produção de alimentos" 47 são toucas descartáveis para mulheres e bonés para homens, que cobrem todo cabelo e não têm perigo de caírem da cabeça, sendo assim mais práticos. O "costume" tem um sentido prático, a "tradição" tem um

46 Segundo o autor, "o termo 'tradição inventada' é utilizado num sentido amplo, mas nunca indefinido. Inclui tanto as "tradições" realmente inventadas, construídas e formalmente institucionalizadas, quanto as que surgiram de maneira mais difícil de localizar num período limitado e determinado de tempo - às vezes coisas de poucos anos apenas - e se estabeleceram com enorme rapidez" (HOBSBAWM, 1997, p. 9).

47 Termo utilizado pela Nutrição, também chamadas de UAN - unidades de alimentação e nutrição. 
sentido simbólico, pois está deslocada de seu "ambiente" original, seja ele espacial ou temporal.

Conforme Eric Hobsbawm,

As "tradições" ocupam um lugar diametralmente oposto às convenções ou rotinas pragmáticas. A "tradição" mostra sua fraqueza quando, como no caso dos judeus liberais, as restrições na dieta são justificadas de um ponto de vista pragmático, por exemplo, alegando-se que os antigos judeus não comiam carne de porco por motivos de higiene. Do mesmo modo, os objetos e práticas só são liberados para uma plena utilização simbólica e ritual quando se libertam do uso prático. As esporas que fazem parte do uniforme de gala dos oficiais da cavalaria são mais importantes para a "tradição" quando os cavalos não estão presentes; (...) as perucas brancas dos advogados dificilmente poderiam ter adquirido sua importância atual antes que as outras pessoas deixassem de usar perucas. ${ }^{48}$

A tradição de se comprar o pão49 na Padaria América é renovada a partir do momento em que os clientes relataram que viam seu pais, avós, tios comprando a broa na padaria, até o dia em que chega o momento em que eles próprios começam a comprar lá. "Então eu via meu avô, depois minha mãe, minhas tias sempre indo comprar broa, pão lá. Depois chegou uma época que eu ia".50

Eles eram ensinados a comer essa broa por seus pais, até a hora em que eles passam a comprá-la e a comê-la da mesma forma que foram ensinados a comer; nas mesmas ocasiões, com as mesmas "cerimônias" e "ritos". Assim eles renovam essa tradição. Até que chegará o momento em que seus filhos passarão a comprar o pão lá, para novamente reestabelecerem a tradição. A cada momento de ruptura a tradição é renovada e fortalecida.

Lindamir comenta: "É, os clientes estão mudando, porque dos clientes antigos, um morre, outro morre, envelhece. Quando não é o neto é o filho que vem... Conheço os fregueses antigos, mas são poucos os fregueses bem antigos, que vem de bengalinha: 'Nossa! Você ainda está aí Lindamir?' E eu digo: 'ainda!'”. ${ }^{51}$ Segundo a mesma, os clientes que compravam na padaria quando ela começou a trabalhar lá, em 1960, "eram alemães mesmo. Ficavam bravos porque a gente não falava o alemão. Mas eles sabiam pedir as coisas em brasileiro (sic)".

48 HOBSBAWM, E.; RANGER, E. (orgs.). A invenção das tradições. 2. Ed. Rio de Janeiro: Paz e Terra, 1997, p. 11-12.

49 * Aqui falamos sobre a broa, mas pode-se remeter esta questão a outros produtos da padaria.

50 HARLEZKI, loc. cit.

51 LECHENAKOSKI, loc. cit. 
A Padaria América hoje estabeleceu uma tradição que seus proprietários querem manter a todo custo, seja pelo significado que a padaria e a própria tradição apresenta a eles, aos seus clientes e aos funcionários, seja pela questão empresarial: tradição também se comercializa, nostalgia se vende. Seus donos sabem que se quisessem viver apenas vendendo "pão francês" seria difícil manter-se neste mercado. "... se nós não tivéssemos o movimento que tem, nós já tínhamos fechado isso fazia muito tempo! Não tem como sobreviver... Se for para fazer 'francesinho' que os outros fazem (...) não sobrevive". ${ }^{52}$

É por causa das broas, dos pães, dos doces tradicionais, que a Padaria América se torna única neste mercado. É por isso que Alfonso comenta que é complicado modificar o que está funcionando.

Hoje ocorre o surgimento de uma clientela nova na padaria, que a freqüenta pelo motivo que apresentamos, ou seja, ser tradicional. São pessoas que não se enquadram no perfil dos clientes tradicionais, não pertencem à cadeia destes, mas a procuram pela tradição construída pela família Engelhardt e por estes clientes. Eles vão atrás da padaria pelo que ela representa. Hoje essa tradição acabou sendo um marketing para a padaria. Na placa de entrada, nos cartuchos de embalagem, no cartão de propaganda, nos calendários o conceito de tradição está presente.

$\mathrm{E}$, quando o conceito não está presente textualmente, se encontra implícito. Todo o ambiente da padaria faz com que esta tradição seja sempre lembrada, seja pelas funcionárias antigas, seja pelos detalhes da loja, como os potes de vidro.

Acreditamos que este marketing não interfere na ida dos clientes tradicionais à padaria. Os clientes confirmam nossa teoria dizendo que eles já têm uma tradição estabelecida e continuam a freqüentar a padaria por causa desta tradição. Petra relata: “... Então quem conhece como eu, vou por causa da minha mãe, aquele vai, vai a minha irmã, a gente foi ontem, a minha sobrinha vai... Então a gente tá passando de geração para geração".

Sr. Ivo também relata:

... Então é uma questão assim, de tradição que a gente costuma ir lá sempre buscar o pão lá... Depois também pela qualidade do produto que eles vendem. É uma firma assim com gente antiga aqui de Curitiba, Os Engelhardt, a família Engelhardt muito antiga. Então, vem dali aquele vínculo, então a gente aos poucos vai formando aquele

52 ENGELHARDT, loc. cit. 
vínculo, aquela tradição, pela qualidade. Então é por isso que a gente está comprando lá toda semana.

Confirmando essa teoria, segundo Lindamir, os doces tradicionais do tempo de Bruda, continuam fazendo, vendendo a mesma coisa, pois os clientes dos "finais de semana" preferem os doces tradicionais. Eles até comentam sobre os doces novos, dizem que são muito bons. Também compram estas novidades, mas não deixam de lado os produtos que são tradicionais da mesa de cada família. Outras tradições se destacam dentro da padaria: a tradição do Schrotbrot que só é vendido nas terças e quintas-feiras; a tradição da torta Aída: "... e quando chega o Natal e a Páscoa tem uma placa que diz: encomendas da torta Aída até tal data";53 a tradição dos sonhos, como conta D. Elfi: "Ah! Os sonhos deles, que eles só fazem aos sábados. Também é outra tradição, também tem muita procura. Se chegar mais tarde já não tem mais".

\section{Considerações finais}

A tradição hoje estabelecida pela Padaria América foi sendo construída e fortalecida por diversos fatores e em diversos momentos, momentos estes intimamente ligados ao contexto curitibano. Dois fatores, conceitos opostos, foram a base da estrutura desta tradição: conservadorismo e inovação.

O conservadorismo se traduz em medidas tomadas pela família para preservação da qualidade: manutenção de matériasprimas; manutenção de funcionários antigos; manutenção do "artesanal" sem produtos químicos; manutenção das receitas e dos seus ingredientes, tentando também fazê-las com os mesmos procedimentos e métodos usados pelo avô e bisavô e para isso mantendo equipamentos antigos. Esta conservação tem finalidade prática, como observamos através de ações específicas.

Porém, o conservadorismo também existe sem ter, no entanto, um sentido prático, como é o caso do chapéu usado por Eduardo Henrique, neste caso, uma "tradição inventada". Essas "tradições inventadas" são eminentemente simbólicas.

Para a família Engelhardt a tradição é a conservação da família em administrar a padaria e fazer o pão de forma artesanal, com matéria-prima de boa qualidade. Nós fazemos o pão. ${ }^{54}$ Para eles, tradição também é a transmissão do comprar e do comer os pães

53 HARLEZKI, loc. cit.

54 ENGELHARDT, loc. cit. 
da padaria de pai, para filho e para neto; de geração para geração. Os clientes de Eduardo Henrique hoje são os filhos e netos dos clientes de seu avô e bisavô, porque ele nasceu comendo nosso pão e ele vai continuar comendo nosso pão e o filho dele vai comer o nosso pão. 55

Alfonso e Eduardo Henrique acreditam que a tradição de sua família não pode acabar em respeito aos seus antepassados e ao sobrenome da família. Porque tudo isso aqui tem um peso, é a minha história também. ${ }^{56}$ Essa tradição também deve permanecer em respeito a outra tradição: a dos clientes.

Para a família, a tradição se conserva por causa da manutenção da qualidade. Este discurso já era verificado nas entrevistas que Bruda deu aos jornais. "Procuramos sempre as melhores matérias-primas, não substituímos ingredientes e nunca usamos produtos químicos". ${ }^{57}$ Porém esta qualidade também se traduz em inovações: receitas novas para acompanhar o mercado e atrair mais clientes; controle de produção e de sobras, para evitar o desperdício; procedimentos para diminuição de filas como novos caixas e novas máquinas de embalar; adoção de uniformes para os padeiros, significando mais higiene. Ou seja, mais organização e profissionalismo.

Os clientes confirmam que a qualidade é um fator importante na escolha da padaria e seus pães. Porém, observamos que outros fatores são da mesma forma importantes para essa escolha. Fatores subjetivos, às vezes inconscientes, porém, podem ser mais importantes que a qualidade. A procura por esse lugar e por seus pães e doces é uma busca por sentimentos, emoções. Uma busca pela tradição, pela memória coletiva dessa sociedade. E, através desta memória despertada, que também é estruturada pelas tradições culinárias e pelos espaços locais, ocorre uma reestruturação ou redefinição de identidades tanto individuais quanto coletivas.

Com relação à identidade étnica, observamos indícios de uma afirmação ou resgate de identidade étnica através do "comer a broa de centeio dos Engelhardt". Falamos em "indícios", pois não podemos afirmar por não terem sidos pesquisados mais profundamente outros dados importantes à esta análise.

Para esses clientes, as mudanças ocorridas na padaria são significado de "evolução" e "progresso". Porém, essas mudanças não interferem em suas escolhas culinárias. Esses clientes preferem

55 Id.

56 Id.

57 Bruda em entrevista para OLIVEIRA, Clécio. Vargas. "Padaria América - Há 73 anos fazendo com capricho, o pão nosso de cada dia”. Indústria e Comércio. 17 de julho de 1986. 
os doces tradicionais e compram os produtos que fazem parte de suas tradições alimentares transmitidas no meio familiar. Em primeiro lugar, vão em busca da broa de centeio, mantendo um hábito alimentar trazido pelos imigrantes alemães e europeus em geral.

Eles procuram uma padaria que está na mesma região há cerca de 90 anos para comer uma broa que também é feita há 90 anos por alguns padeiros antigos - que estão trabalhando ali, em média, há 40 anos - e por um integrante da família Engelhardt, que teve esses ensinamentos repassados pelo avô, tendo este recebido os ensinamentos de seu pai. Eles pedem essa broa para balconistas, algumas com 35 anos de casa, e, na hora de pagar, encontram a irmã dessas balconistas, que está há mais de quarenta anos como funcionária dessa padaria.

Esses clientes vão em busca de manutenção de raízes, manutenção de tradição que para eles também se traduz em permanência de valores familiares refletindo na própria estrutura familiar. Vocêe nunca pode esquecer o que você foi no passado, seja ele bom ou ruim. Raízes, não é? A gente tem que ter raízes em algum lugar.58 Eles procuram isto nesta empresa familiar, onde o pai supervisiona e seus três filhos trabalham.

Segundo a família Engelhardt, a padaria só permanece no mercado por causa desta clientela fiel, que compra os produtos tradicionais. E para manter esses produtos, é necessária a qualidade, que significa muitas vezes conservação, tradição. Isso faz com que ocorra uma nova clientela que é atraída pelo diferencial da padaria, que é sua história, sua tradição.

Também podemos afirmar que essa tradição se mantém por que está sendo sempre atingida por mudanças, pela inovação. Essas transformações são feitas de uma forma sutil e cautelosa para serem bem recebidas pelos clientes. É nesses momentos de tensão, de ruptura, que a tradição se fortalece. A tradição é fortalecida pelo constante caminhar conjunto do conservadorismo e da inovação.

E assim, a Padaria América permanece com suas permanências e mudanças produzindo o pão das gerações curitibanas.

58 MAKAROV, loc. cit. 